\title{
CDISC SDTM Risk Assessment Terminology
}

National Cancer Institute

\section{Source}

National Cancer Institute. CDISC SDTM Risk Assessment Terminology. NCI Thesaurus.

Code C101848.

Terminology associated with the risk assessment codelist of the Clinical Data

Interchange Standards Consortium (CDISC) Study Data Tabulation Model (SDT M). 